\title{
MARKET ANALYSIS OF ENTERPRISE RESOURCE PLANNING SYSTEMS WITH FOCUS ON UKRAINE
}

\section{Vasyl Grygorkiv}

Chernivtsi National University, Chernivtsi, Ukraine

\section{Andrii Verstiak}

Chernivtsi National University, Chernivtsi, Ukraine

\author{
Mariia Grygorkiv \\ Chernivtsi National University, Chernivtsi, Ukraine
}

(C) MESTE NGO

JEL Classification: D47, D82, L22, L86

\begin{abstract}
The main trends and forecasts of Ukrainian IT-market are described in the study. The main attention was paid to ERP-systems. There are suggested strategies in accessing the Ukrainian IT market with a view to minimize potential risks and delays. The major problem for Ukrainian companies is non-stability of running business in Ukraine which often results in the absence of real long term strategic plans of the enterprise development. This is a real problem for the use of informational technologies. The fact is that while the informational technology is in use only to solve local tasks and improve some business processes, it does not require the strategic approaches and fits completely the common pattern of national enterprise management when its activities are planned maximum for a year period.
\end{abstract}

Keywords: ERP, IT-market, Ukrainian IT sphere, accessing IT-market, Countries of Central and Eastern Europe (CEE), Commonwealth of Independent States (CIS)

\section{INTRODUCTION}

Transformational conversion of the Ukrainian enterprises caused by the market economy reforms and globalization processes is of paramount importance due to the joining of Ukraine the World Trade Organization (WTO). A great number of the Ukrainian enterprises has

Address of the corresponding author:

Vasyl Grygorkiv

麦”” emmvsh@gmail.com been owned by transnational companies or have drawn actively foreign capital investments. It stipulates a certain change in enterprise management approaches which are alike those of Western managers'. It concerns, largely, the implementation and use of modern information systems and technologies.

In real problems of IT-management and ERP implementation in UKRAINE are explored only by ERP-vendors and consulting companies such as: 
SAP, Microsoft, GAAP, IDC, CONIM etc. (Verstiak, 2012).

The answer as for expediency or non-expediency of enterprise automation has been known for a long time. However the problems of the choice of the kind of informational system, the way of its designing, programming and implementation, the degree of automation of business processes and information system integration in Ukraine are still open for the discussion.

\section{IT-MARKET IN CEE AND CIS COUNTRIES: KEY TRENDS}

According to free analysis (PMR, 2013) Russia has the biggest IT market from amongst all the CEE and CIS countries: in 2012 the market accounted for almost $50 \%$ of regional IT market sales. By contrast, the Romanian market in 2012 created little more than $3 \%$ of the market value represented by the analyzed countries of CEE and CIS. In 2012, the IT market in Poland, considered to be the second-largest market among these CEE and CIS countries, amounted to $20 \%$ of regional IT market sales. Despite the country's huge population, Ukraine's market value only reached about $4 \%$ of the total. The Czech Republic, by contrast, is doing pretty well: its population (almost five times smaller than that of Ukraine) accounted for a share valued at almost $12 \%$ of the total analyzed market (PMR, 2013).

In Russia, computer hardware remains the largest segment within the IT market: it has a market share by value of almost $58 \%$. IT services has a market share of approximately $27 \%$; software follows with more than 15\% market share (PMR, 2012). This market structure is only partially explained by the ongoing high rate of software piracy in the segment of home users and small businesses. The main reason for this structure is the investment orientation of IT spending in the country. Russian IT companies still earn most of their sales from the implementation of new IT systems (or upgrades and expansion); hardware is the largest budget expense in these IT projects.

The IT market structure in Ukraine is dominated by the hardware market, whose market share is more than $77 \%$, followed by IT service's market share of more than $13.5 \%$, and the software market's market share of more than $9 \%$. Other countries have similar market structures: the hardware market has the highest market share of more than $40 \%$; the software market share accounts for around $20 \%$; IT services maintains a market share of approximately 30-40\% (PMR, 2013).

In Russia, the value of the IT products and services segment increased to RUB 678.2 billion (EUR 17 billion) in 2012. This represents 15\% more than in the preceding year. The majority the country's leading vendors, distributors and system integrators reported growth in sales revenues last year (PMR, 2013). One should note that the devaluation of the Russian ruble is accountable for about half of the market growth. The Russian IT market depends on imported hardware and software. IT project budgets are often designed to take into account the exchange rate with the US dollar.

The last three years on the Polish IT market should be assessed as favorable. The growth rate, although lower than initially thought, remained definitely positive. The market value exceeded levels seen in 2010. The positive trend continued. As mentioned above, the IT market does not function separately from macroeconomic factors, including global factors. Even though this industry in Poland is relatively resistant to market fluctuations, the performance and stock prices of IT companies are not fully resilient to general market sentiment. Beginning in 2014, the growth rates of all of three segments - hardware market, software market and IT services - are going to decline slightly (PMR, 2014).

The statistics, data and macroeconomic indicators gathered by PMR, as well as its forecasting models built on those, indicate a slight growth on the telecommunications market in the region in 2013 to a total of $€ 65$ billion (PMR, 2013). The CEE countries seem to be quite homogeneous when it comes to the telecommunications market trends and tendencies. However, some regional, country-characteristic differences appear. One should also remember that not all the CEE telecom markets are evenly competitive, which can ultimately create some rigidities and cause visible differences among analyzed countries. For instance, PMR market experts forecast that in countries such as the Czech Republic and Poland, the value of the telecommunications sector will diminish this year. 
The total value of the Russian telecommunication services market increased by $6 \%$ year on year to approximately $€ 31.4$ billion in 2012 (PMR, 2013). The market reached maturity. Its overall growth was driven by niche services including mobile internet access and content distribution. Traditional voice telephony and wired broadband showed either relatively modest development last year or stagnations in sales. In subsequent years, the main challenge on the market for telecommunications operators will be to adapt to its relatively modest overall growth and stagnation in voice services.

The value of the Polish telecommunications services market in 2012 was $€ 9.2$ billion, a decrease of over $2.2 \%$ compared with 2011 . The negative trend has continued in 2013 (PMR, 2014). Nevertheless, in PMR's opinion, the value of the telecommunications market in Poland will bounce back in 2014-2015 thanks to the mobile telephony and data transmission segments. It is worth bearing in mind that in recent years MTR reductions have had a relatively significant impact on the value of the mobile services market in CEE. The value of the telecommunications market in the Czech Republic for instance has been declining for the last four the years and not only due to strong competition among providers and overall economic slowdown. In 2012, the value of the Czech mobile market dropped by as much as $12 \%$ to $€ 2.5$ billion and the negative trend will maintain this as well. In general, mobile telephony markets in CEE are already characterized by a very high level of saturation and, as a result, are growing slowly in terms of SIM card numbers (PMR, 2014). They are often declining due to wholesale market regulation and price competition. It is important to note that, despite the high penetration level measured by the number of SIM cards in the statistics presented by operators, a proportion of the population in the CEE countries still does not have a mobile phone.

Interestingly, the Romanian telecommunications market has been able to stop the erosion of revenues. In 2012, the total value of the telecommunications services market in Romania stood at $€ 3.6$ billion, which was almost $3 \%$ up year on year (PMR, 2013). The star of the telecommunications industry over the next few years will remain the data transmission and internet services provision segment, which will record the highest advance in the entire market. The DLISP market will reach the $€ 1$ billion milestone in 2018.

\section{UKRAINIAN ERP MARKET}

Actually all national enterprises have started automation with the implementation of accounting informational systems, using typical the so-called "box" solutions which were very useful at the initial stage partially meeting the demands of management. Thus, it has been successfully completed the computerization of the financial accounting including the automated formation of bookkeeping and calculation of taxes. More perspective seems to be with managerial accounting which under the conditions of automated informational systems is based on practically unlimited analysis and the possibility of operative formation of accounting which, in its turn, is calculated on the basis of absolute and reliable bookkeeping information.

But the problems of automation of supplies, manufacture, distribution, logistics, personnel management, basically the problems constituting the core of enterprise activities and profit are still remain open. Sometimes certain spheres are automated. Such an approach allows some advantages for a certain employee who enables to reduce the number of mechanical errors, the number of routine operations, accelerate their performance. If it is possible, the attempts are made to export/import the data among different informational systems which are to automate different tasks by different technologies. The use of the local approach to the automation problem does not permit to consider comprehensively all the processes that take place at an enterprise and to analyze them from the point of view of systemic analysis.

For Ukraine nowadays, the tasks of the economic growth, increasing of production quality and competitiveness, becoming a member of the world market are most topical. The solution of these tasks without the increase of the quality management and automation of all spheres of economy (state bodies of management, different enterprises and small businesses) is impossible.

The major problem is non-stability of running business in Ukraine which often results in the absence of real long term strategic plans of the 
enterprise development. This is a real problem for the use of informational technologies. The fact is that while the informational technology is in use only to solve local tasks and improve some business processes, it does not require the strategic approaches and fits completely the common pattern of national enterprise management when its activities are planned maximum for a year period. When an enterprise wants to implement the ERP system in full scale and not for solving local tasks, then may arise some problems. And the implementation of such a system is a constituent of the business development strategy. If this factor is not taken into consideration by the company the negative consequences are evident. The only way out for this is to agree the strategic goal of the company with the purposes of implementation of the informational system. In any other case the purposes ERP system implementation will have a declarative character, thus the project is doomed to be a failure.

The IT market of Ukraine has been characterized by the consulted Ukrainian experts (Matyas, 2012) as the one market sector in Ukraine that has been developing with highest capacities and speed compared to international standards over the last years. Within the IT sector the telecommunication market has been described to cover the biggest segment with $7 \%$ of the annual turnover followed by the hardware market with $25 \%$. The third position is being taken by services with $9 \%$ including software developers and outsourcing. A considerable part of the market with $5 \%$ of the annual turnover is generated by game developing enterprises in Ukraine (Kuhar, 2013).

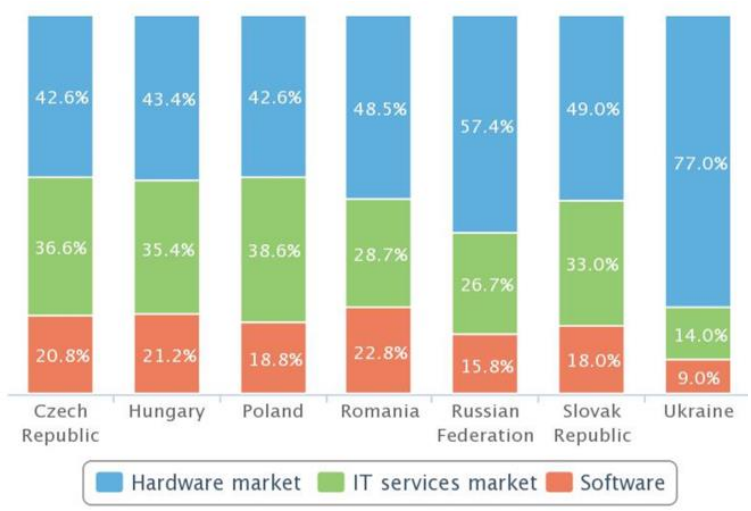

Fig. 1 IT-market structure in selected CEE and CIS countries \%, (PMR, 2012)
Taking into account the high volatility of the market development, the market's structure has been forecasted by the consulted Ukrainian experts to develop into the following proportions up to year 2012: hardware - 77\%; software (including outsourcing) - 9\% and IT services market - 14\% (PMR, 2012).

IT-sphere growths very dynamically in Ukraine. The next figure shows part of IT to GDP over last 6 years. Based on the calculations that projected growth in domestic IT industry (35-40\% per year) by 2015 we will have $8 \%$ of IT to GDP.

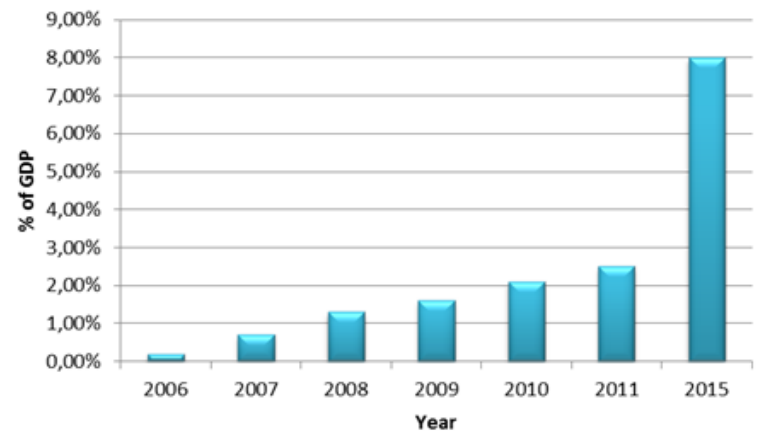

Fig. 2 IT-sphere in Ukraine (Anon, 2012)

The speed of growth of IT-market outperforms GDP growth. This means that the tendency of saturation of the global market, are not typical for Ukraine.

The difference between the issues solved by ERP in the West and in Ukraine, the same as between the goals of a crowded passenger transport: those who are inside want to get a seat as comfortable as possible, while those outside - to squeeze the least at the first stair. From the beginning of 2008 to the end of 2010 Ukrainian IT-market has experienced one of the most difficult periods. Vendors and consulting companies gave an unprecedented discount, offered attractive options of purchase and payment in installments, but in most cases it was extremely difficult to find new customers for implementing ERP-systems. As a result, the sector in terms of money last year decreased by $60-80 \%$. Now it is time to recovery industry. However, it is not the same as before. Segment of the enterprise management system has undergone many changes in quality.

The market of ERP-systems is the part of the information and communication industry, which, in turn, brings together the two main sectors: Communications and Information Technology. 
Western ERP-systems (automation of enterprise management) appeared in the Ukrainian market in the early '90s. The first office was opened by the company SAP AG. After it other Western ERPdevelopers and consulting companies began to work in Ukraine and by the end of the 90 in the Ukrainian market there were present nearly all the leading Western ERP-vendors. After several years of experiments and failures associated with the development of "Ukrainian (post USSR) conditions" (weak regulation and standardization of business processes, a very-very specific kind of accounting and frequent changes in laws) the companies began successful implementation of Western systems, constituting a serious competition to the domestic "Parus" and "Galaxy" (Anon, 2012).

In the early 2000s, the domestic IT market, contrary to global trends, grew at an accelerated rate. In this period ERP-systems were one of the most attractive segments of IT-market. The market of corporate software in Ukraine is also influenced by general economic situation.

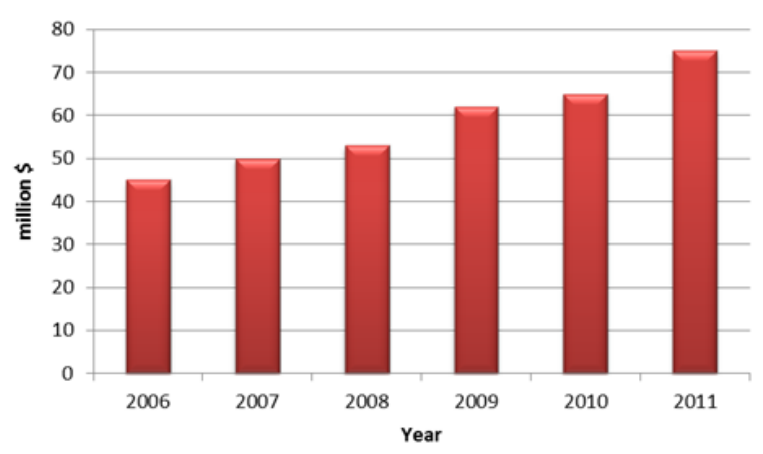

Fig. 3 Ukrainian market of ERP-systems, (Anon, 2012)

A considerable part of incomes within the ERP market is achieved by direct sales. At the same time a significant growth of income from license sales, involved systems and IT consulting support has been. The license sales contributed significantly to the dynamic growth of 2010 and the increase of incomes from technical support of constantly growing clients base was especially pointed out as noticeable for those companies that have been long established within the Ukrainian market, and were able to form a substantial number of customers.

The high demand originating from Ukrainian companies for ERP systems will be continued all through 2014 and even beyond. It was stated that the important national economic growth in the majority of sectors combined with the estimated political stabilization could stimulate the interest of foreign and native investors for long-term investments into production in Ukraine. It was highlighted that one important factor of increasing ERP system demand is the currently ongoing process of consolidation inside of several economic branches. Newly groups of companies and holdings need sufficient software and licenses in order to allow them to integrate different information systems into one management control system. According to estimations of the Ukrainian IT consulting enterprise IDC a high potential of growth have such ERP systems in industrial sectors within sales and distribution, banking sector and governmental and public administration. The speed of growth of these sectors will be higher than Ukrainian ERP market growth in general, which has been estimated to reach 26\% per year until 2015 (Anon, 2012). The governmental and public administration sector has been considered to be the main customer of ERP systems in terms of license volume. Governmental institutions show a lot of interest to systems of corporate management. The realization of large IT projects in customs and rating authorities is expected within a short timeframe (Anon, 2012).

We predict a rise of native enterprise management software with additional functionality (CRM function, supply-chain management, workflowmanagement etc.). Similar to the ERP systems market we predict this development to come up in the very near future. Some Ukrainian companies are already focusing on this IT market segment such as "Parus" and "Galaktika". The Ukrainian experts highlighted the continuing change of demand from universal management systems towards very specialized industry solutions that take into account peculiarities of the economic fields and involve typical resolving applications of industry specific tasks.

As we see the leader is SAP. The sales exposure to a market of SAP ERP solution in the CIS in 2011 was $52.5 \%$, in $2012-53 \%$. There was increasing sales of: business intelligence solutions for the management of procurement and financial management of the company, as well as information management, personnel, etc. 
Table 1. The leaders of the Ukrainian ERP-market, $\%$ (Verstiak, 2012)

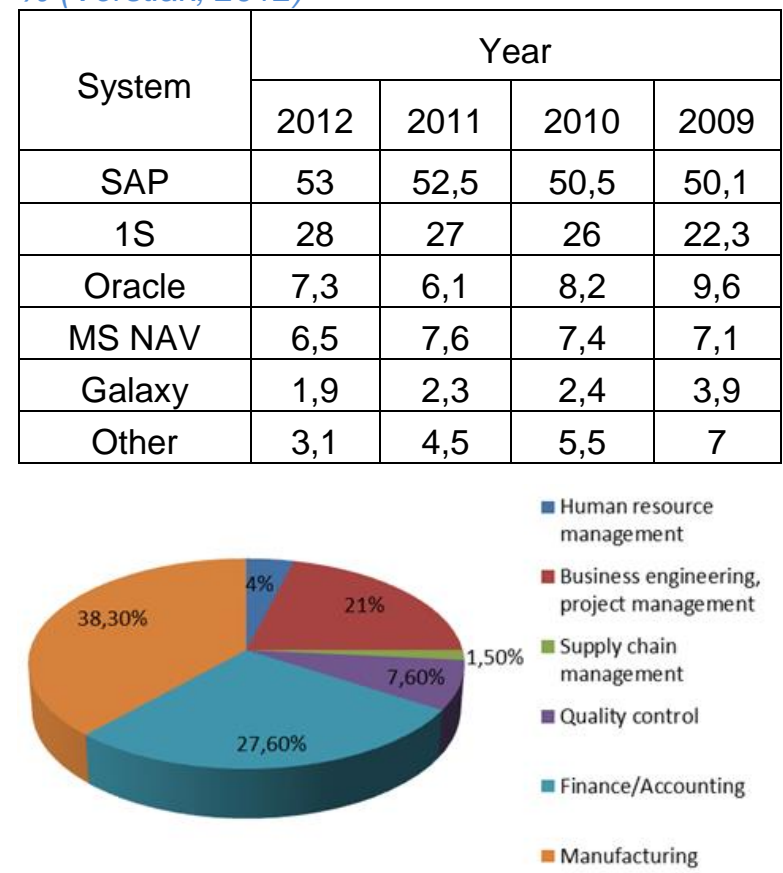

Fig. 4 The modules of implemented ERPsystems (Verstiak, 2012)

The modules of implemented ERP-systems are divided as it is shown on Fig. 4.

\section{MAIN TRENDS AND FORECASTS OF THE UKRAINIAN ERP-MARKET}

Let us discuss the main trends and forecasts of the Ukrainian ERP-market.

- The high demand from Ukrainian companies in the ERP-system will continue in 2014-2015, considerable growth in most sectors of the economy and political stability will stimulate the interest of both foreign and domestic investors to long-term investments in production.

- An important factor in the demand for ERP. systems is ongoing processes of consolidation within industries: the newly created group of companies and holdings need software that allows integrating disparate information systems into a single management tool.

- The rise of demand of ERP-systems is expected from companies preparing for the placement of shares on Western stock markets and seeking to improve the investment attractiveness for investors through transparent business practices. In 2014-2015 more than 20 Ukrainian companies will spend initial public offering (IPO) which provide an additional impetus to the development of ERP-market and increased demand for systems that support a Western accounting standards. For the same reasons of transparency the Ukrainian market branches and representative offices of foreign companies form demand for ERP-systems.

- Such industries as retail, banking and public sector have significant potential for growth. The growth rates of these segments will outpace the growth of much of Ukrainian ERP market as a whole. The main candidate for the role of "locomotive" of the market of ERPsystems is considered to be the public sector. Today, government agencies show increased interest in systems of corporate governance. In support we want to mention new SAP customers: "Prominvestbank", "Naftogaz of Ukraine", "Credit Dnepr", "Farmak", and "First Ukrainian investment bank".

- In the near future ERP-systems market is expected to increase the number of domestic management software company, which sold more Internet functionality (CRM-functions, supply chain management, etc.).

- When choosing a partner customers pay more attention for the presence in a consulting company the experience of the success of similar projects.

- Today customers are interested in primarily proven industry solutions used by similar businesses not only in the world, but also in Ukraine. Risks of introduction of such software are much lower than in the implementation of standard ERP-systems.

- With the increasing quantity of implemented ERP-systems we should see the increasing of the demand for maintenance such systems. Sales exposure for companies that provide services to support information systems should be expanded. But in reality we do not see it. For this reason, in many companies on the base IT department own professional teams are formed. These teams are able independently to deal not only with the support of information systems, but also with their adaptation to changing market conditions and business demands.

- One of the bottlenecks impeding the development of ERP-systems market in Ukraine remains a shortage of skilled workers: consultants, programmers, designers of business processes.

Let us suggest strategies in accessing the Ukrainian IT market with a view to minimize potential risks and delays.

We pointed out that opportunity for entering into the Ukrainian IT market for foreign investors have 
become more difficult because domestic investors have started to utilize their competitive advantages and do realize intensive market research. Let us list the highest economic perspectives for investment for the following spheres of activity:

- Software Development;

- Software sales, distribution and locally administrated maintenance;

- Hardware Design and Assembly.

On the other hand we must highlight the Program of intensification of investment processes into the Ukrainian IT market, which is carried out by the Ministry of Economic Affairs of Ukraine and does include the following activities:

- forming of government-entrepreneur delegations with the goal of carrying out conferences and presentations in the economic centers of potential customers of Ukrainian IT developments;

- support for Ukrainian private companies through governmental initiatives for participating in first-rate international exhibitions and summits

- support for Ukrainian private companies through governmental initiatives on applying to tender principles with public examination;

- planning and execution of international PR and business awareness programs to establish a Ukrainian branding as country with IT potential;

- editing of legislative acts of Ukraine with the goal of ensuring security for foreign and native investments into the IT industry;

- development of a system of additional administrative privileges for foreign representations (e.g. visa support, regional support initiatives at the level of local authorities, that will provide simplicity and quickness in registration of new branch

enterprises, including $100 \%$-foreign
business).

\section{CONCLUSIONS}

Considering the fact that Ukrainian ITprofessionals have qualifications similar to Russians, and that their salaries are $30-50 \%$ lower, it is not surprising that Russia holds the 4th place among the countries where Ukraine's key software development orders are originating due to low international recognition of Ukrainian IT industry and little on-site presence of software development companies. A plenty of individual and consolidated activities are expected in this field in the near future. Also, a significant raise of foreign investors' interest to Ukrainian IT companies and their products international commercialization is forecasted. The neighboring European Union countries and special cooperation status with EU are also deemed as favorable factors for Ukrainian IT-export industry growth. Some positive factors for developing of export IT market are listed below:

- professionalism and high level of qualification of specialists;

- strong research potential and investment attractive innovation technologies;

- relatively low salaries of qualified specialists of the sector;

- stable growth of Ukrainian economics and especially strong increase of export IT sector; - growth of investment appeal of Ukraine in whole and IT sector particularly;

- neighborhood with EU and competitiveness of Ukrainian hi-tech culture. The most perspective centers for development of IT export capacities Kyiv, Kharkiv, Lviv, Vinnica, Odessa, Crimea, Zaporizhya and Dnipropetrivsk in terms of already available infrastructure and qualified staff.

\section{WORKS CITED}

Anon (2012). Evolution of ERP: http://ko.com.ua/jevolyuciya_erp_72787

Anon (2012). IDC investigations: http://www.idcukraine.com

Anon. (2012). Implementation of ERP-solutions: http://corp.cnews.ru/news/line/index.shtml?2012/11/29/421833

Anon. (2012). On the threshold: http://ko.com.ua/na_poroge_72722

Kuhar, A. (2013). Ukrainian market of business applications: it's time to SMB. http://ko.com.ua/ukrainskij_rynok_biznes-prilozhenij_prishlo_vremya_smb_50252

Matyas, M. (2012). Director SAP Ukraine. Interview: http://itbusiness.com.ua/it-business-week/interview/31258-sap-.html

PMR. (2012). IT market in Ukraine 2012. Retreived from PMR publications:

http://www.pmrpublications.com/product/IT-market-Ukraine-2012 
PMR. (2013). PMR Online - IT \& Telecommunications. Market intelligence portal for: Bulgaria, Czech Republic, Hungary, Poland, Romania, Russia, Slovakia, Ukraine. Retrieved from PMR publications: http://www.pmrpublications.com/product/en_market_intelligence_IT_telecommunications_CEE_CIS

PMR. (2014). Telecommunications market in CIS countries 2014. Retrieved from PMR publications: http://www.pmrpublications.com/product/Telecommunications-market-in-CIS-countries-2013

Verstiak, A. (2012). Ukrainian IT-industry characteristics. Economics. Bulletin Chernivtsi Trade Institute. 3(6). 79-84.

Received for publication:

Revision received:

Accepted for publication:
12.03.2014

26.09.2014

14.10.2014

\section{How to cite this article?}

Style - APA Sixth Edition:

Grygorkiv, V., Verstiak, A., \& Grygorkiv, M. (2015, Jan 15). Market analysis of enterprise resource planning systems with focus on Ukraine. (Z. Čekerevac, Ed.) MEST Journal, 3(1), 87-94. doi:10.12709/mest.03.03.01.10

Style - Chicago Fifteenth Edition:

Grygorkiv, Vasyl, Andrii Verstiak, and Mariia Grygorkiv. 2015. "Market analysis of enterprise resource planning systems with focus on Ukraine." Edited by Zoran Čekerevac. MEST Journal (MESTE) 3 (1): 87-94. doi:10.12709/mest.03.03.01.10.

Style - GOST Name Sort:

Grygorkiv Vasyl, Verstiak Andrii and Grygorkiv Mariia Market analysis of enterprise resource planning systems with focus on Ukraine [Journal] // MEST Journal / ed. Čekerevac Zoran. - Belgrade : MESTE, Jan 15, 2015. - 1 : Vol. 3. - pp. 87-94.

Style - Harvard Anglia:

Grygorkiv, V., Verstiak, A. \& Grygorkiv, M., 2015. Market analysis of enterprise resource planning systems with focus on Ukraine. MEST Journal, 15 Jan, 3(1), pp. 87-94.

Style - ISO 690 Numerical Reference:

Market analysis of enterprise resource planning systems with focus on Ukraine. Grygorkiv, Vasyl, Verstiak, Andrii and Grygorkiv, Mariia. [ed.] Zoran Čekerevac. 1, Belgrade : MESTE, Jan 15, 2015, MEST Journal, Vol. 3, pp. 87-94. 